\title{
Assessment of Flash Flood Hazard Degrees of Wadi EL Tarfa, Eastern Desert, Egypt: Using GIS Based Morphometric Analysis Technique.
}

\author{
Mohamed Abu Setta ${ }^{1}$, Hassan Garamoon ${ }^{2}$ and Ashraf Shabana ${ }^{3}$ \\ ${ }^{1}$ Geology Department, Desert Research Center, Cairo, Egypt.mohamedsaid_p@sci.asu.edu.eg \\ ${ }^{2}$ Geology Department, Faculty of Science, Ain Shams University.h_garamoon@sci.asu.edu.eg \\ ${ }^{3}$ Geology Department, Desert Research Center, Cairo,Egypt.ashrafshabana@ymail.com
}

\begin{abstract}
Wadi EL Tarfa basin is one of the largest basins in the Eastern Desert of Egypt where its surface area reaches $4939 \mathrm{Km}^{2}$. It is considered one of the promising agricultural reclamation areas in Egypt. Wadi EL Tarfa is mainly running on El Maaza limestone plateau and drains in the Nile River at the southeast of BeniMazar City. The morphometric analyses of Wadi El Tarfa was carried out through ARC GIS software 10.2 based on DEM with resolution of $30 \mathrm{~m}$ (SRTM 1 Arc-second Global) which downloaded online from the USGS site. Wadi El Tarfa basin is subdivided into eight main sub-basins (from 1 to 8). According toStrahler ordering method, Wadi EL Tarfa attains eighth order and its sub-basins range between fifth order for small sub-basins (nos.1, 3, 4\& 6) and seventh order for large sub-basins (nos. $7 \& 8$ ). The flash flood hazard degrees of El Tarfa basin have been estimated depending on the morphometric parameters which have direct effect on the flood amount. The morphometric ranking method was used in determining the hazard degrees which are divided into five hazard classes. All sub-basins are classified according to the degrees of hazard. The classification shows that the subbasin (no. 2) has the lowest hazard while sub-basins (nos. 3, 5, 6\& 8) are the most hazardous. The resultant flash flood risk maps indicate the most probable sub-basins and the main roads expected to be affected by flood hazard. It is recommended to construct protection systems in Wadi El Tarfa area such as retardation earthen dams to mitigate the floods risk in one hand and to increase the rain water harvesting on the other hand.
\end{abstract}

Keywords: Flash flood hazard, Wadi EL Tarfa, morphometric analyses,Eastern Desert, Egypt.

DOI : doi.org/10.46617/icbe6004

\section{Introduction}

Flash flood is considered one of the major natural disasters which causes large amount of deaths and damage [1]. In arid zones, flash flood is an unexpected phenomena which occur suddenly as result of the high intensity of rainfall precipitation during short time over specific areas of the catchment, causes large damage of infrastructure and in some times effects extent to lose of life. Flash flood occurs due to high intensity rainy storm over the catchment areas which characterized by steep slope and sparse vegetation cover and it occur sudden with high velocity flows [2].

Egypt suffers from shortage in the water resources. The Nile River is the main source of water in Egypt with limited storage of the groundwater resources. Generally, the high intensity rain storms is considered double-edged sword which can be led to flash flood risk or can be used as a source of fresh waterstorage. The main objectives of this study are to eatimate and assess the flash flood hazard degrees in Wadi El Tarfa basin and 
recommend sites for constructive retardant and storage dams to mitigate the flash flood hazard and to increase the rain water harvestingbased on the morphometric analyses.

According to the rapid advanced of the remote sensing technology and related programs, the geographic information system (GIS) is considered one of the most important techniques used in morphometric analyses and delineating the boundaries of the watershed of the basins. The morphometric analysis is an important technique for both hydrological and hydrogeological researches and gives an overview about the surface geometry and the behavior of the surface with the runoff water in the drainage basin. It helps in the evaluation of the hydrological characteristics of the basin to assess the availability of thewater resources [3].

Wadi El Tarfa is located in the eastern side of the Nile Valley at south east Beni Mazar City, El Minia Governorate, Egypt, (Fig.1). It is bounded from east by the Red Sea drainage system (Wadi El Hawashiya), from west by the Nile River, from south by Wadi El Bustan and Wadi El Siririya and it is bounded from north by Wadi El Mihasham and Wadi Sannur. It is considered one of the largest basins in the Eastern Desert which drains in the Nile River. It has a surface area that reaches about $4939 \mathrm{~km}^{2}$, covered mainly by carbonate rocks of Cretaceous and Eocene ages.

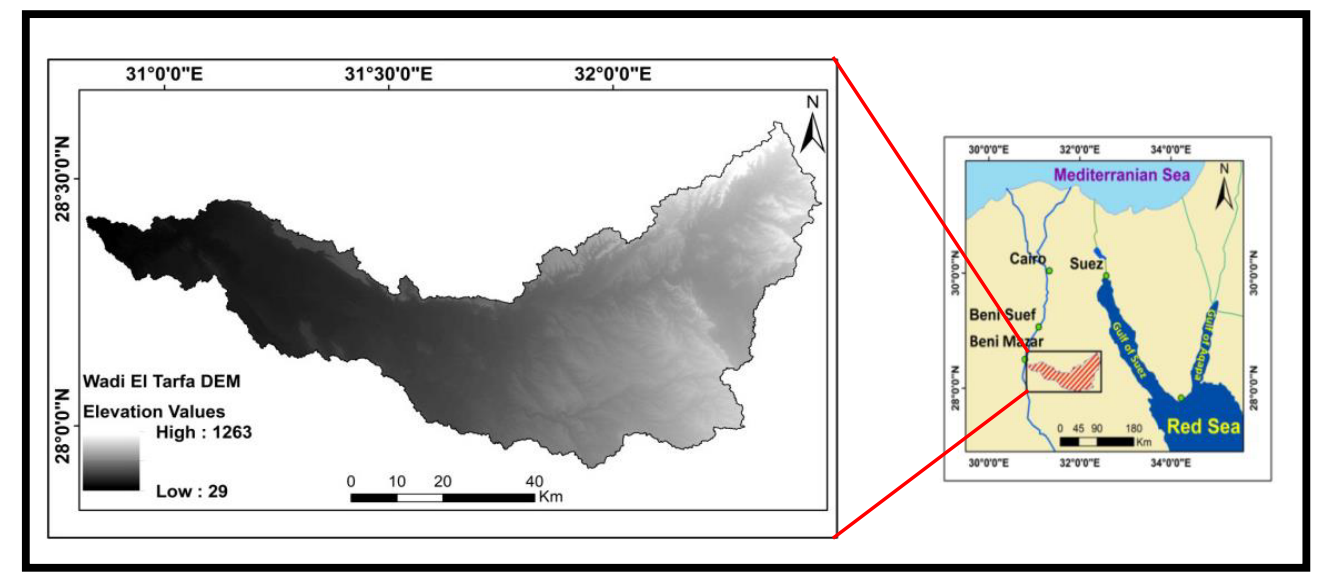

Fig (1): Location map and Digital Elevation Model of Wadi El Tarfa.

Flash flood hazard of Wadi El Tarfa has been evaluated based on morphometric ranking method by using ten morphometric parameters that involve density (D), frequency (F), area (A), relief ratio (Rr), shape index (Ish), circularity ratio (Rc), gradient ( $\mathrm{S} \%$ ), bifurcation ratio $(\mathrm{Rb})$, length of overland flow (Lo) and the sinuosity index $(\mathrm{Si})$, [4]. 
The stream orders of Wadi El Tarfa have been determined using Strahler's ordering method, [5]. Wadi El Tarfa is subdivided into eight main sub-basins (Fig.2). It attains eighth order and its sub-basins range between fifth order for small sub-basins (nos.1, 3, 4\& 6) and seventh order for large sub-basins (nos. 7\& 8). All eight sub-basins as well as Wadi El Tarfa itself have been subjected to morphometric analyses through different morphometric parameters to evaluate the degrees of flash flood hazards and determine the best sites to induce the effective recharge the Eocene groundwater aquifers.

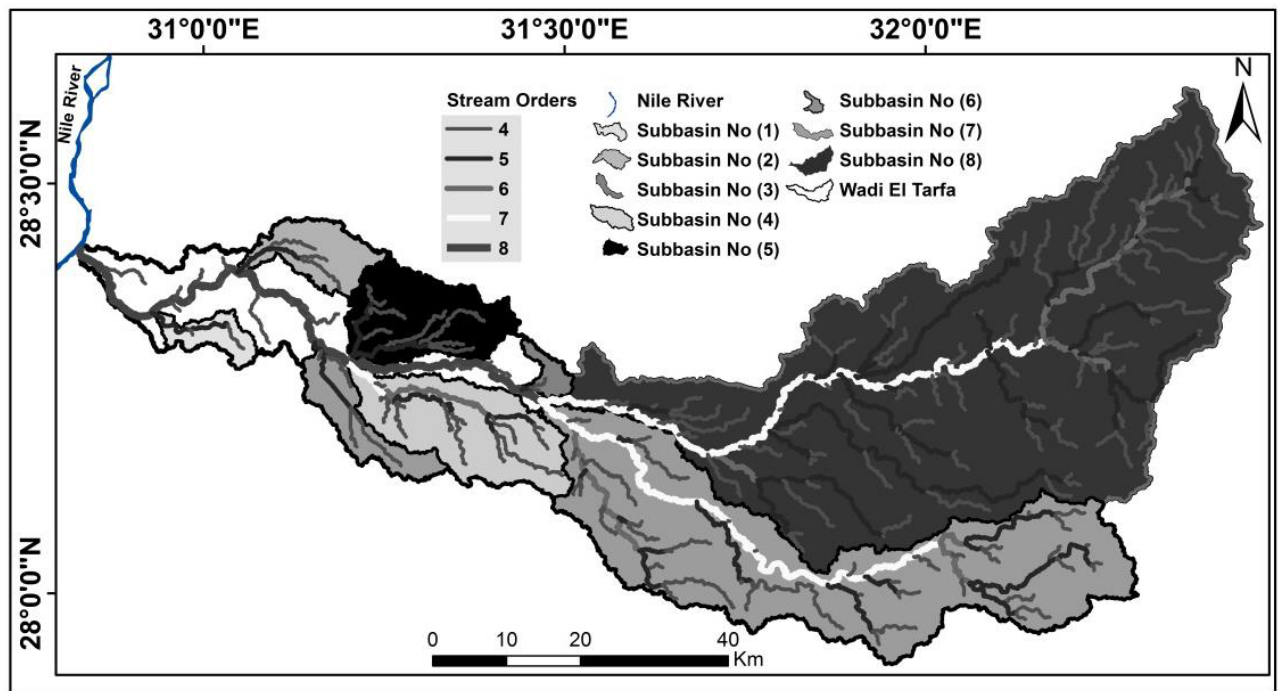

Fig (2): The main drainage network of Wadi El Tarfa and its sub-basins.

\section{Material and Methods}

The extraction of the main drainage network of Wadi El Tarfa as well as the morphometric analysis has been performed based on Digital Elevation Model (DEM) with resolution $30 \mathrm{~m}$ that derived from Shuttle Radar Topography Mission (SRTM 1 ArcSecond Global) which obtained from the USGS siteby using ARC GIS software 10.2 (Fig.1) [6]. The topographic maps (scale 1:50,000 and 1:500,000) have been used in the verification of the watershed outlines of Wadi El Tarfa. The geological map of Conoco, (1987) has been used for the delineation of the structural lineaments to calculate the structural lineaments density [7]. The flow chart of the main steps for production the flash flood risk maps are shown in (Fig.3).

The estimation of the flood risk degrees have beenestimated by using morphometric ranking method based on the morphometric analyses of thirteen parameters which have direct effect on the flooding (Table.1). The morphometric ranking method is a statistical method in which each parameter is classified into five classes with five rank categories of risk, [8-9] depend on the following equation [9]:

$$
\text { Risk equation }=\frac{\text { Max }- \text { Min }}{5}
$$


Where: Max: maximum value of each morphometric parameter, Min: minimum value of each morphometric parameter

Table (1): Hazard degrees of the sub-basins of Wadi El Tarfa.

\begin{tabular}{|c|c|c|c|c|c|c|c|c|c|c|c|c|c|c|c|c|}
\hline \multirow{3}{*}{ No } & \multirow{3}{*}{ Basin Name } & \multicolumn{13}{|c|}{ Hazard Degrees of Morphometric Parameters } & \multirow{3}{*}{ Total } & \multirow{3}{*}{$\begin{array}{r}\text { Hazard } \\
\text { Degree }\end{array}$} \\
\hline & & \multicolumn{9}{|c|}{ Direct Relationship } & \multicolumn{4}{|c|}{ Reverse Relationship } & & \\
\hline & & $\mathbf{A}$ & $\mathbf{D}$ & $\mathbf{F}$ & Rc & Ish & Rt & $\mathbf{R r}$ & Rn & $\mathrm{SI} \%$ & WMRb & Lo & $\mathbf{S i}$ & Sld & & \\
\hline 1 & $\begin{array}{c}\begin{array}{c}\text { Sub-basin } \\
\text { (no. 1) }\end{array} \\
\text { (n) }\end{array}$ & 1 & 1 & 3 & 3 & 1 & 1 & 2 & 1 & 2 & 5 & 1 & 1 & 5 & 27 & 2 \\
\hline 2 & $\begin{array}{c}\text { W. Abu - } \\
\text { Thumaymat, } \\
\text { (no. 2) }\end{array}$ & 1 & 1 & 1 & 3 & 3 & 1 & 1 & 1 & 2 & 3 & 1 & 2 & 3 & 23 & 1 \\
\hline 3 & $\begin{array}{c}\begin{array}{c}\text { Sub-basin } \\
\text { (no. 3) }\end{array} \\
\end{array}$ & 1 & 5 & 5 & 1 & 1 & 1 & 1 & 1 & 1 & 1 & 5 & 4 & 5 & 32 & 5 \\
\hline 4 & $\begin{array}{c}\begin{array}{c}\text { Sub-basin } \\
\text { (no. 4) }\end{array} \\
\end{array}$ & 1 & 1 & 1 & 5 & 2 & 2 & 1 & 1 & 1 & 4 & 1 & 3 & 3 & 26 & 2 \\
\hline 5 & $\begin{array}{l}\text { W. Abu } \\
\text { Kibithat, } \\
\text { (no. 5) }\end{array}$ & 1 & 1 & 1 & 5 & 5 & 2 & 4 & 1 & 1 & 4 & 1 & 3 & 5 & 34 & 5 \\
\hline 6 & $\begin{array}{c}\text { Sub-basin } \\
(\text { no. } 6)\end{array}$ & 1 & 1 & 3 & 3 & 1 & 1 & 5 & 1 & 5 & 4 & 2 & 5 & 2 & 34 & 5 \\
\hline 7 & $\begin{array}{c}\text { W. Abu } \\
\text { Ghaza, (no. } \\
7 \text { ) }\end{array}$ & 3 & 1 & 1 & 1 & 1 & 3 & 2 & 4 & 3 & 3 & 1 & 1 & 4 & 28 & 3 \\
\hline 8 & $\begin{array}{l}\text { W. Abu } \\
\text { Sayyal, } \\
\text { (no. 8) }\end{array}$ & 5 & 1 & 1 & 2 & 1 & 5 & 3 & 5 & 2 & 4 & 1 & 1 & 1 & 32 & 5 \\
\hline
\end{tabular}

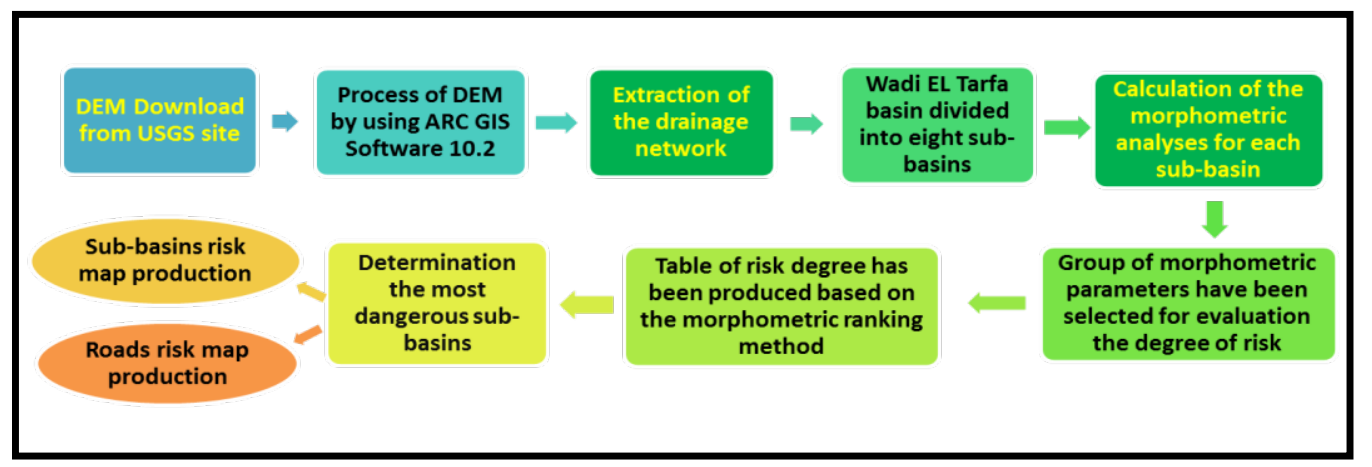

Fig (3): Flow chart for the production of the flash flood risk map.

\section{Results and Discussion}

Thirteen morphometric parameters have been selected for estimating the flash flood hazard degrees which have direct impact on the flooding and these parameters are classified into two groups as follows, as shown in (Table.1):

1. Group (I): contain nine morphometric parameters which have direct proportion with flood hazards and these parameters are the basin area (A), drainage density (D), stream frequency $(\mathrm{F})$, relief ratio $(\mathrm{Rr})$, ruggedness number $(\mathrm{Rn})$, texture ratio $(\mathrm{Rt})$, slope index (SI\%), circularity ratio (Rc) and basin shape index (Ish).

2. Group (II): contain four morphometric parameters which inversely proportional with flooding hazards and these parameters are the weighted mean bifurcation ratio 
(WMRb), length of overland flow (Lo), structural lineaments density (Sld) and sinuosity index $(\mathrm{Si})$.

Each parameter is classified into five class intervals with five rank categories of risk. For group (I) rank (1) refer to lower risk degree while rank (5) refer to higher risk and for group (II) rank (1) refer to higher risk degree while rank (5) refer to lower risk. Then all risk degrees of all different parameters for each sub-basin are summed and the collected values are also classified into five class intervals with five rank categories of risk by using the pervious equation, rank (1) refer to lower risk degree while rank (5) refer to higher risk degree. The risk values range between 23 (W. Abu Thumaymat (no.2) and 34 (W. Abu Kibithat (no.5) and sub-basin no.6) (Table.1). The summation degrees of hazard of each sub-basin represent the degree of flood hazard of this sub-basin which is relative value to any other sub-basin.

The class intervals of flood hazard degrees are classified in ascending order and all subbasins are classified into five classes of hazard depending on these class intervals as follows:

1. Weakly hazardous; for class interval (23-25.2) which is represented by (W. Abu Thumaymat (no.2)) with risk degree 1.

2. Slightly hazardous; for class interval (25.3-27.4) which isrepresented by (sub-basins nos. 1 and 4) with risk degree 2.

3. Moderately hazardous; for class interval (27.5-29.6) whichis represented by (W. Abu Ghaza (no.7)) with risk degree 3.

4. Highly hazardous; for class interval (29.7-31.8) with risk degree 4.

5. Extreme highly hazardous; for class interval (31.9-34) which isrepresented by (subbasin (no.3), sub-basin (no.6), W. Abu Kibithat (no.5) and W. Abu Sayyal (no.8)) with risk degree 5.

Two different risk maps have been produced. The first one represents the flood risk map of the sub-basins of Wadi El Tarfa which indicates:

1. Sub-basins (nos. 3, 5, $6 \& 8$ ) are the most dangerous sub-basins in Wadi El Tarfa and it needs the priority of the protection systems to mitigate the expected flood hazard, (Fig.4).

2. Sub-basin (no.7) is moderately hazard.

3. Sub-basins (nos. 1, $2 \& 4$ ) are safe and reflect the probability of recharging the shallow carbonate aquifers in Wadi El Tarfa, (Fig.4).

The second map represents the flood risk maps of Wadi El Tarfa and its sub-basins on the main roads passing through it which indicates:

1.Wadi Abu Sayyal (sub-basin no.8) represents high risk on a large area of El Shiekh Fadl - Ras Gharab road as indicated by arrows (Fig.5).It is recommended to construct a protection system for El Shiekh Fadl - Ras Gharab road as it crossing the concerned sub-basin, (Fig.5). 
2.Wadi El Tarfa in general represents high risk on the roads as indicated by arrows (Fig.6). It is recommended to construct a protection system at the intersection of main channels with all roads passing through it (El Shiekh Fadl- Ras Gharab road, Cairo Assuit road and Cairo - Aswan road) (Fig.6).

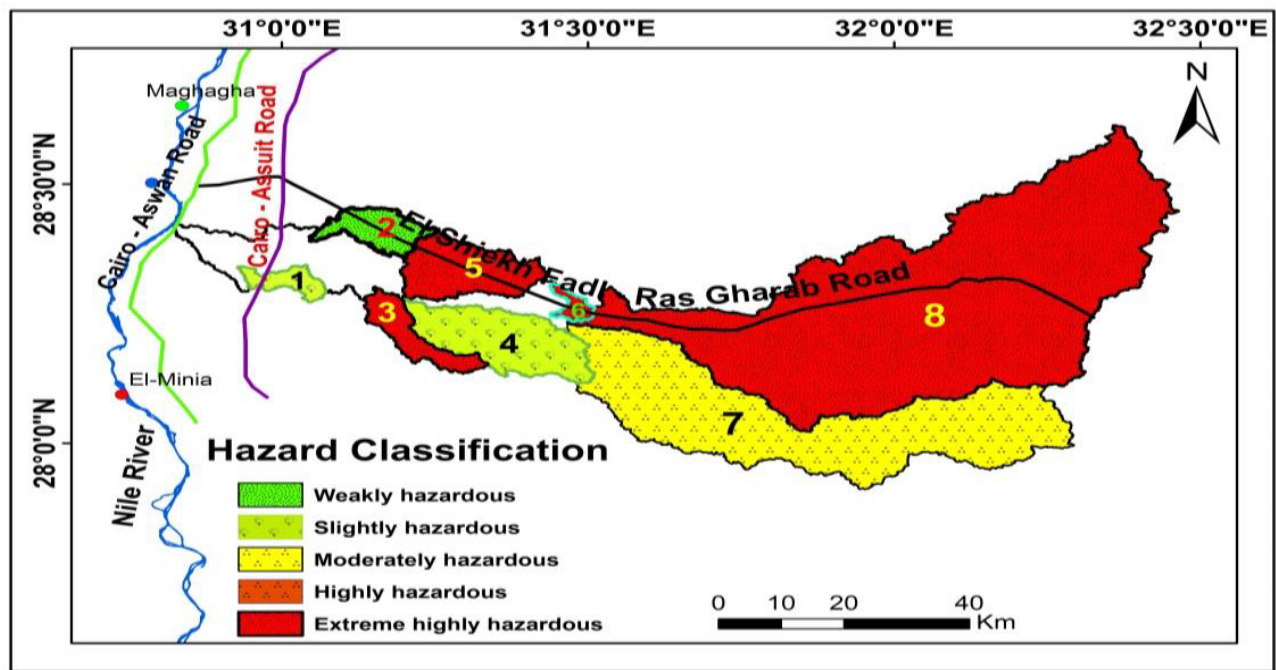

Fig (4): Flood risk map of the sub-basins of Wadi El Tarfa.

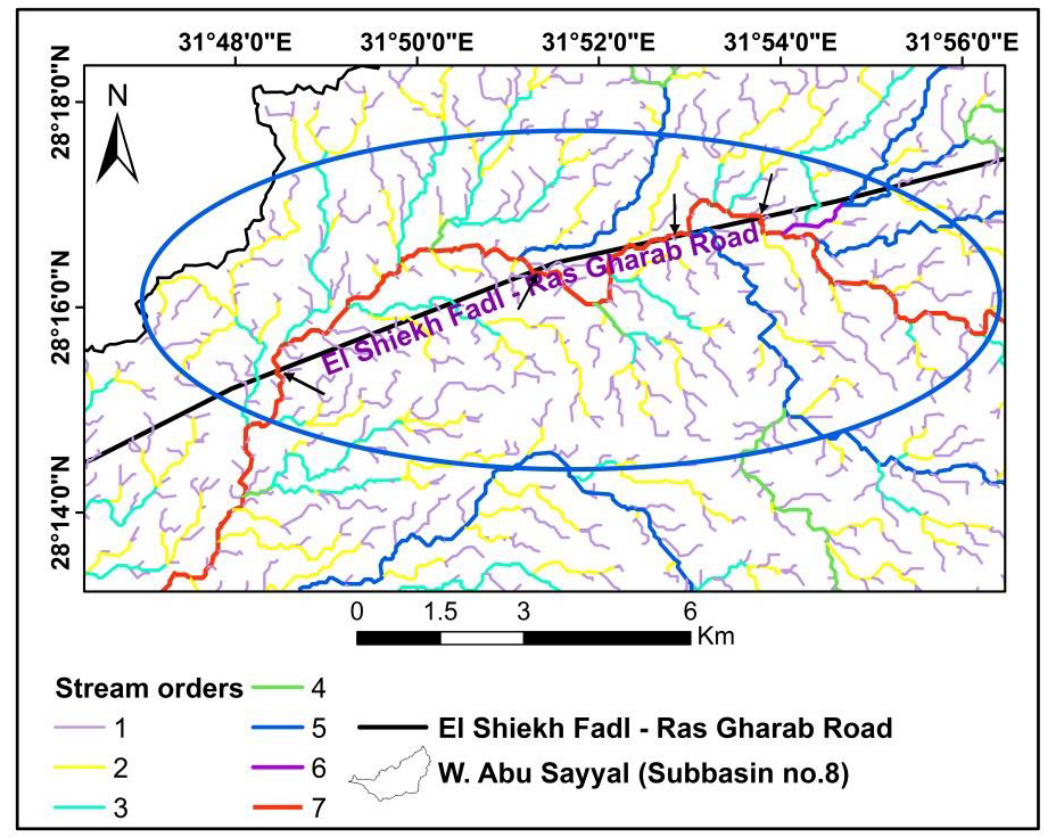

Fig (5): Risk map of Wadi Abu Sayyal (no.8). 


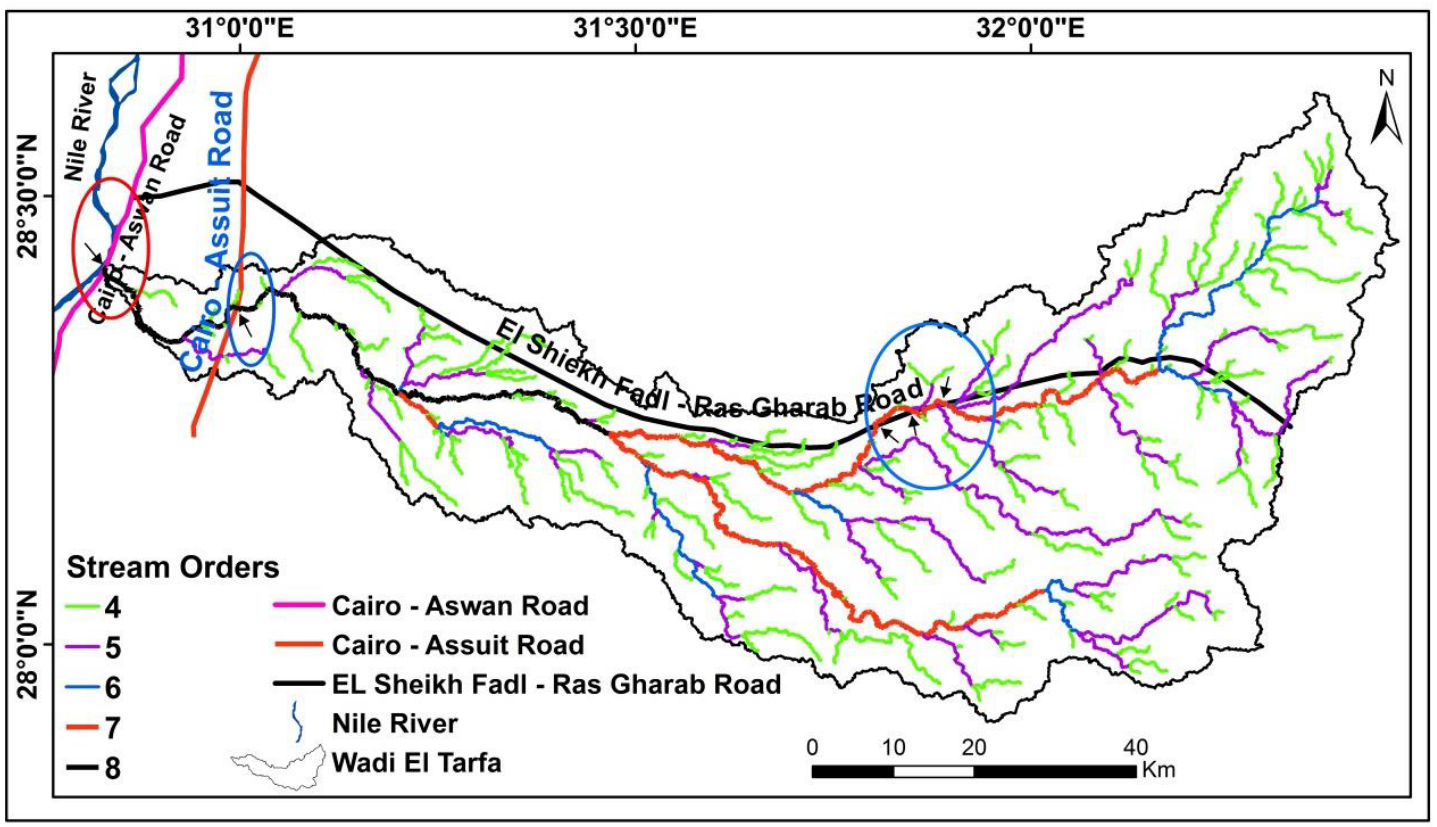

Fig (6): Wadi El Tarfa risk map on the main roads.

According to the estimated flash flood hazard degrees, sub-basins (nos. 3, 5, 6\&8) have the highest degrees of risk, so the mitigation systems such as artificial barriers, retardation earthen dams and storage dams are recommended at the up stream and the down stream portions of these sub-basins to mitigate the effect of flooding in one hand and to harvest the surface runoff on the other hand. Sub-basins (nos. 1, $2 \& 4$ ) have the lowest hazard degrees which illustrate the surface runoff water reaches from the up stream to the down stream in long duration as well as the high rate of infiltration due to the geological nature of the high fractured intensity in the limestone terrain, so these subbasins reflect the possibility of recharging the shallow carbonate aquifers in Wadi El Tarfa.

The field study in (November 2018) revealed the presence of aprotection systemwhich was constructed under Cairo-Aswan road (Fig.7). It is also observed accumulations of runoff water on both sides of El Shiekh Fadl - Ras Gharab road at Wadi Abu Kibithat (sub-basin no.5). It is recommended to construct a protection tools at the intersection of the concerned sub-basin with the road (Fig.8).
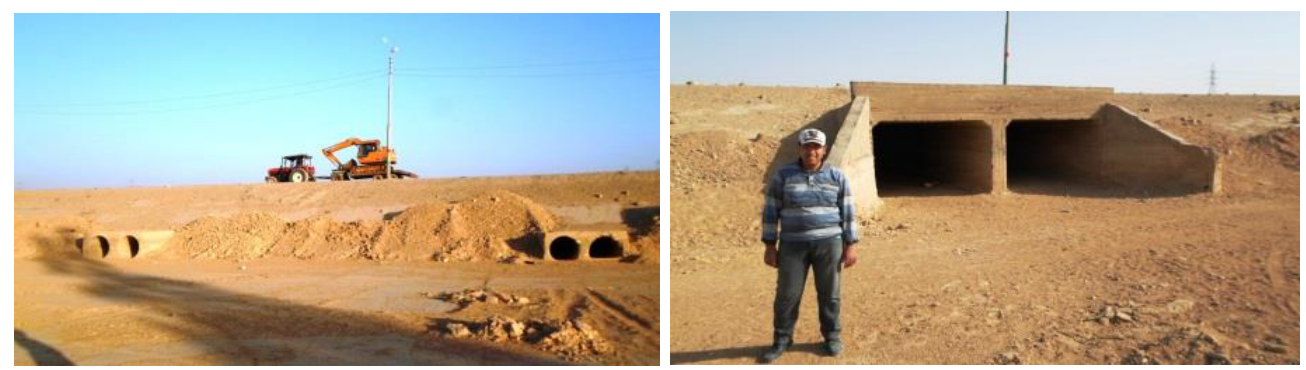

Fig (7): Field photographs showing the protection systems at Cairo - Aswan road $(22 / 11 / 2018)$. 

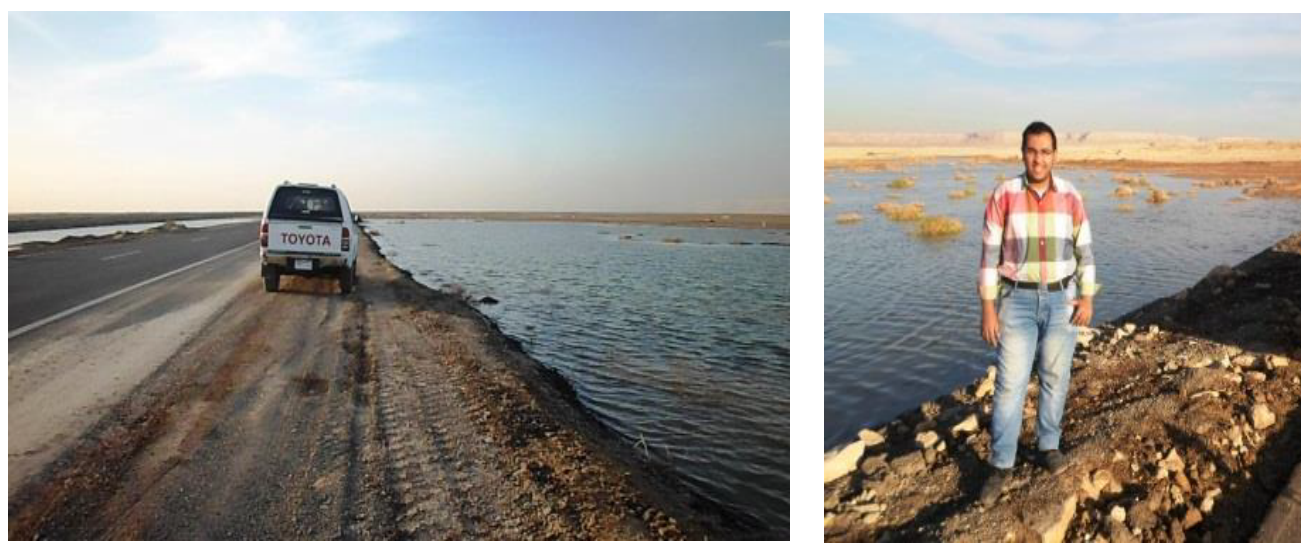

Fig (8): Field photographs showing the runoff water on both sides of El Sheikh Fadl RasGharab road (20/11/2018).

\section{References}

[1]CEOS (2003): The use of earth observing satellites for hazard support, assessments and scenarios. Final report of the CEOS Disaster Management Support Group (DMSG).

[2] Xiao, L. (1999): Flash Floods in Arid and Semi-Arid Zones. International Hydrological Program, Technical Documents in Hydrology, No. 23, UNESCO, Paris.

[3] Khadri, S. F. R., (2013): Morphometric analysis of Bordi River Basin, Akola District Maharashtra, India, using remote sensing and GIS techniques. IJPRET. Department of Geology, Vol. 1(9), p.1-21.

[4] Shabana, A. R., (2014): Geology of water resources of Wadi EL Tarfa, Eastern desert, Egypt: Egyptian Journal of Geology, Vol. 58, P. 23-42.

[5] Strahler, A. N., (1952): Hypsometric (area-altitude) analysis of erosional topography. Geol. Soc. America Bull, 63, 1117-1142.

[6] Https://earthexplorer.usgs.gov.

[7] Conoco (1987): Geological Map of Egypt, Scale (1:500,000), NH 36 SW- BeniSuef sheet.

[8] Aggour, T. A. O., (1999): Priorities of flood insurance, Gulf of Aqaba region, Southeast Sinai, Egypt. Desert. Inst. Bull., Egypt. Vol.49, No. 2, p.371-400.

[9] Youssef, A. M., Pardhan, B. and Hassan, A. M., (2011): Flash flood risk estimation along the St. Katherine road, southern Sinai, Egypt using GIS based morphometry and satellite imagery. Environ Earth Sci, Vol. 62, p.611-623. DOI 10.1007/s12665-010-0551-1. 


\title{
The efficacy of Vancomycin resistant of Leuconostoc spp. Isolated from UTI patients in Mosul city-IRAQ
}

\author{
Aws Ibrahim Sulaiman \\ Biology department / College of Science / University of Mosul \\ Email:aws_isulaiman@yahoo.com
}

\begin{abstract}
Leuconostoc species are gram-positive, non-motile, non-spore-forming, hetero-fermentative, facultative cocci that are found in the environment. They have economic importance because of their use in the dairy and pickling industries and in wine making. Leuconostoc species are also found in fermented sausages, vacuum-packed meat products, cereals, and dairy products (butter, cream, fresh/raw milk, cheese) and causes diseases for human like brain abscess and urinary tract infections which are very similar in the shape like streptococcus and other related genera.
\end{abstract}

We were collected 41 midstream urine samples from 14 Male and 27 Female patients came to ALKHNSAA Teaching Hospital and Al-Salam Teaching Hospital in Mosul city-IRAQ. We obtained only 3 (7.3\%) of Leuconostoc spp. out of 41 according to identification tests, biochemical tests and resistance to vancomycin which is important test for this bacteria.

We were study the ability of Leuconostoc spp. to grow in different temperature and different media. Leuconostoc spp. can grow only on nutrient agar at $10{ }^{\circ} \mathrm{C}$ and they can growth at $25^{\circ} \mathrm{C}$ on both blood agar without hemolysis and Leuconostoc Selective media (LSM). Leuconostoc spp. were sensitive to $\operatorname{IPM}_{10}(32 \mathrm{~mm} /$ disk $)$ and $\mathrm{CIP}_{10}(27 \mathrm{~mm} /$ disk $)$, respectively and all of them were resistance against other antibiotics under study ( $\mathrm{AM}_{10}$, $\mathrm{E}_{15}, \mathrm{CN}_{10}, \mathrm{P}_{10}, \mathrm{VA}_{10}$ and $\left.\mathrm{TMP}_{10}\right)$.

Keywords: Leuconostoc spp., LSM, BHIA+VAN .

\section{Introduction}

Phenotypically, Leuconostoc spp are catalase-negative coccobacilli or cocci that produce gas from glucose, all of them are intrinsically resistant to vancomycin. Species members like L. mesenteroides were isolated from human clinical specimens (Horowitz, et al., 1987and Facklam and Elliott, 1995).

Leuconostoc spp. caused bacteremia has been documented predominantly in patients with underlying malignancies (acute myeloid leukemia, non-Hodgkin's lymphoma, hepatocellular carcinoma) and as a complication of solid-organ (e.g., liver) and stem cell transplantation and they can organisms also colonize indwelling intravenous catheters, resulting in catheter-related bacteremia's, meningitis, breast abscess, abdominal abscess and peritonitis (Jofré et al., 2006).

Nosocomial urinary tract infections may also develop; again, in those patients on long-term vancomycin therapy as opportunistic pathogens.

Leuconostoc species have been isolated from brain and liver abscesses, osteomyelitis, and pulmonary infections in compromised and debilitated patients (e.g., 
gastroenterology patients, burn patients, AIDS patients) and as agents of spontaneous bacterial peritonitis and peritonitis in CAPD patients (Buu-Hoi, et al., 1985).

Despite remaining uncommon but these pathogens are gaining importance as opportunistic agents of human infections associated with high mortality rates in the last decade where, Leuconostoc spp. have been reported with increasing frequency as human pathogens, causing (Helali et al., 2005 and Procop, et al., 2017).

Leuconostoc spp. have been implicated in a variety of infections. The first cases of Leuconostoc infection in humans was reported at 1985 as the risk factors of infection include antibiotic pressure, foreign device, or underlying immune defects. Characteristics that differentiate the Leuconostoc spp. from other members of the catalase-negative, gram-positive lactic acid cocci are production of carbon dioxide during the fermentation of glucose. These microorganisms have an important physiological marker related to their intrinsic resistance to vancomycin but successfully treated with penicillin (Albanese, et al., 2006 and Kulwichit, et al., 2007).

Leuconostoc spp. are often mis-identified as Lactobacilli, Streptococci, Pediococci or Enterococci as all these genera share several biochemical properties but different in their behavior towered produced acid from glucose (Mahon, et al., 2015).

The aim of research to isolate and identify this microbe as the first time in our city and detect the antibiotic effectiveness against them.

\section{Materials and Methods}

\subsection{Bacterial Samples:}

We were collected 41 midstream urine samples from 14 Male and 27 Female patients visited ALKHNSAA Teaching Hospital and Al-Salam Teaching Hospital in Mosul city. All samples were transferred by Brain Heart Infusion Agar supplemented with $6 \mu \mathrm{g}$ Vancomycin (BHIA $+6 \mu \mathrm{g}$ Van.) to scientific laboratory in biology department / college of Science / University of Mosul immediately and incubated at $37^{\circ}$ at $24 \mathrm{~h}$ (Khudaier, 2011).

\subsection{Identification Tests:}

For cultivation Leuconostoc spp. we were used the medium composed depending on Atlas, (2010) per liter: $\mathrm{CaCO}_{3} 50.0 \mathrm{~g}, \mathrm{NaCl} 2.5 \mathrm{~g}$, Malt extract $50.0 \mathrm{~g}$, Beef extract $1.0 \mathrm{~g}$, Poly-peptone (Peptone + tryptone with equal amount ) 1.0g, Agar 15.0g and distilled / deionized water and bring volume to $1000 \mathrm{ml}$ adjust the $\mathrm{pH} 7.0 \pm 0.2$.

After gram stain we identified our suspected bacteria depending on behavior towered Catalase and hydrolysis Bile Esculine also the ability to ferment multiple sugars (Fructose, Lactose, Maltose, and production $\mathrm{CO}_{2}$ from Glucose fermented using Durham tubes) and growth on blood agar for detected $\alpha$-hemolysis (Finegold and Martin, 1982; Cappelli, et al., 1999 and Alexander and Strete, 2001).

\subsection{The Growth at different temperatures:}

We were incubated the Leuconostoc spp. on blood agar; Leuconostoc agar and Nutrient agar at different temperatures 10,25 and $37{ }^{\circ} \mathrm{C}$ for $24 \mathrm{~h}$ for differentiate and separation Leuconostoc spp. from other related species like Streptococcus spp. and Enterococcus spp. because Leuconostoc(Procop, et al., 2017). 


\subsection{Antibiotic Sensitivity test:}

The isolates which belong to Leuconostoc spp. were tested for the resistance to Ampicillin $\left(\mathrm{AM}_{10}\right)$, Ciprofloxacin $\left(\mathrm{CIP}_{10}\right)$, Erythromycin $\left(\mathrm{E}_{15}\right)$, Gentamicin $\left(\mathrm{CN}_{10}\right)$, Imipenem $\left(\mathrm{IPM}_{10}\right)$, Penicillin $\left(\mathrm{P}_{10}\right)$, Vancomycin $\left(\mathrm{VA}_{10}\right)$ and Trimethoprim $\left(\mathrm{TMP}_{10}\right)$ using disks belongs to Bioanalyzer Company, Turkey and the procedure according to Vandepitte, et al., (2003) and CLSI, (2018).

\section{Results and Discussion}

We obtained $3(7.3 \%)$ isolates out of 41 clinical samples collected after phenotypic identification of Leuconostoc spp. depending on growth on selective media, gram stain, catalase, resistance to vancomycin (the best test for this microbe) and biochemical tests Figures and Tables 1 and 2.

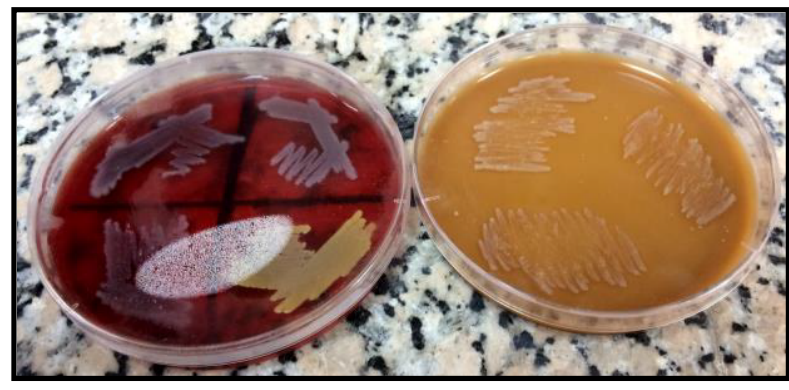

Figure. 1: Leuconostoc spp. on blood agar just the white grayish colonies left and Leuconostoc spp. on Leuconostoc Selective Medium right
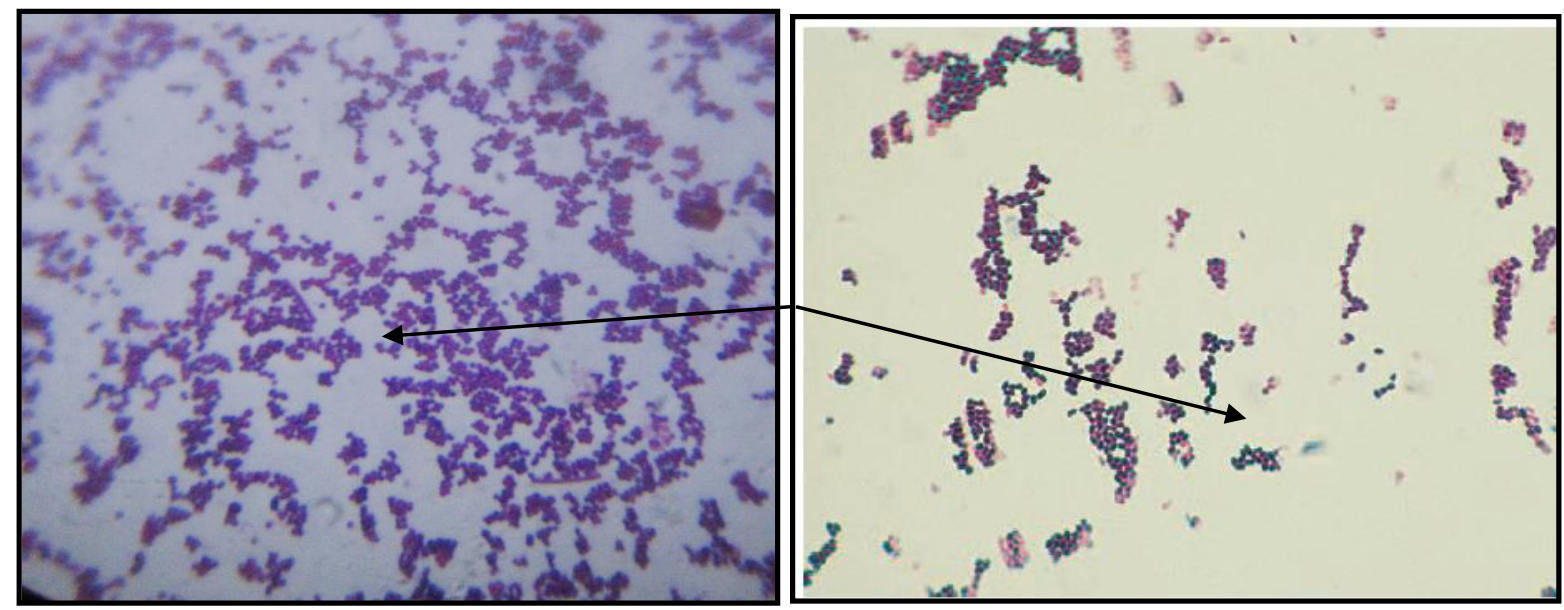

Figure 2: for comparative gram stain of Leuconostoc spp. positive cocci and diplococci (100X) from our local isolates on the left and Leuconostoc spp. standard on the right from Procop. et al.. 2017.

Table 1: Biochemical Identification Tests for selective samples only

\begin{tabular}{|c|c|c|c|c|c|c|c|c|c|}
\hline \multirow[b]{2}{*}{ NO } & \multirow[b]{2}{*}{ Catalase } & \multirow[b]{2}{*}{$\begin{array}{c}\text { Bile } \\
\text { Esculine }\end{array}$} & \multirow[b]{2}{*}{ Urease } & \multirow[b]{2}{*}{$\begin{array}{l}\text { Resistance to } \\
\text { Vancomycin }\end{array}$} & \multirow[b]{2}{*}{$\begin{array}{c}\alpha \text {-hemolysis on } \\
\text { blood agar }\end{array}$} & \multicolumn{4}{|c|}{ Carbohydrate Fermentation } \\
\hline & & & & & & Fructose & $\begin{array}{c}\text { Glucose, } \\
\text { produce } \\
\mathrm{CO}_{2}\end{array}$ & Lactose & Maltose \\
\hline 3 & - & + & - & $\overline{\mathrm{R}}$ & + & + & + & + & + \\
\hline 5 & - & - & - & $\mathrm{R}$ & + & + & + & + & + \\
\hline 6 & - & + & - & $\bar{R}$ & + & + & + & + & + \\
\hline
\end{tabular}


Table 2: Growth at different Temperatures at 24h

\begin{tabular}{|c|c|c|c|}
\hline \multicolumn{3}{|c|}{ Mediums } \\
\hline & Leuconostoc Selective Medium & Blood Agar & Nutrient Agar \\
\hline $10 \mathrm{C}$ & - & - & + \\
\hline $25 \mathrm{C}$ & + & + non hemolytic & + \\
\hline $37 \mathrm{C}$ & + & $+\alpha-$ hemolytic & + \\
\hline
\end{tabular}

The morphology of Leuconostoc species like Streptococcus spp. are grampositive cocci or diplococci, catalase-negative; that are resistant to vancomycin and produce bubbles $\left(\mathrm{CO}_{2}\right)$ gas from glucose fermentation it is very useful for differentiate from other gram positive cocci catalase negative bacteria like (Streptococcus species, Enterococcus species Alloiococcus species, Gemella species, Pediococcus species, and Helcococcus species), Leuconostoc species do not grow at $45^{\circ} \mathrm{C}$ but can grow at $10{ }^{\circ} \mathrm{C}$ and this test it is best for determined from other gram positive cocci catalase negative group also, but Leuconostoc species may be readily misidentified as Streptococci because have a same shape under microscope (Procop, et al., 2017).

The biochemical identification for this microbe are catalase (-), bile esculine (+), growth in the presence of $6.5 \% \mathrm{NaCl}$ and production of gas from glucose $(+)$, produce $\alpha$ hemolysis on blood agar (Elliott and Facklam, 1993 and Mahon, et al., 2011).

From these results we exhibited just 3,5 and 6 isolates, this result was similar to Khudaier, (2011) when he studied Leuconostoc mesenteroides from UTI patients in North India he founded that only 8 isolates out of 558 urine samples was catalase, $\alpha$-hemolysis, resistant to vancomycin and fermentation several carbohydrates and production gas from glucose and these results agreement somewhat to the study of Cappelli and their colleagues, (1999) they founded (five isolates) of Leuconostoc mesenteroides from UTI patients were resistant to vancomycin and production $\mathrm{CO}_{2}$ from glucose fermented.

We think Leuconostoc Selective Medium (LSM) is selective because contain poly peptone as a high source of proteins and salts like some researchers were studied the selective media for this bacteria and they made to develop media for the isolation and enumeration of these organisms, and both selective and differential media have been described; however, no medium has proven to be satisfactory.

There are many media are based on the ability of Leuconostoc to utilize citrate, which is recognized by the presence of halos around colonies growing on media containing insoluble calcium citrate, but not all of them were utilize citrate furthermore; In combination with other ingredients these agents proved to be successful (Benkerroum, et al., 1993 and Moschetti, et al. , 2000).

We achieved the susceptibility towards several antibiotics and the table 3 below explain these results with more details. 
Table: 3 Antibiotics Sensitivity Tests

\begin{tabular}{|c|c|c|c|c|c|}
\hline Antibiotics & $\begin{array}{l}\text { Sensitivity } \\
\text { percentage } \\
\text { (no.) }\end{array}$ & $\begin{array}{c}\text { Resistant } \\
\text { percentage } \\
\text { (no.) }\end{array}$ & Antibiotics & $\begin{array}{l}\text { Sensitivity } \\
\text { percentage } \\
\text { (no.) }\end{array}$ & $\begin{array}{c}\text { Resistant } \\
\text { percentage } \\
\text { (no.) }\end{array}$ \\
\hline Ampicillin $\left(\mathrm{AM}_{10}\right)$ & 0 & 100 & $\begin{array}{c}\text { Gentamicin } \\
\left(\mathrm{CN}_{10}\right)\end{array}$ & 0 & 100 \\
\hline $\begin{array}{c}\text { Amoxicillin/Clavulanic } \\
\text { acid }\left(\mathrm{AMC}_{30}\right)\end{array}$ & 25 & 75 & $\begin{array}{l}\text { Imipenem } \\
\left(\text { IPM }_{10}\right)\end{array}$ & 100 & 0 \\
\hline Cefixime $\left(\mathrm{CFM}_{5}\right)$ & 0 & 100 & Penicillin $\left(\mathrm{P}_{10}\right)$ & 0 & 100 \\
\hline Ciprofloxacin (CIP10) & 33 & 67 & $\begin{array}{l}\text { Trimethoprim/ } \\
\text { sulfamethoxazol } \\
\text { e }\left(\mathrm{TMP}_{10}\right)\end{array}$ & 0 & 100 \\
\hline Erythromyicn $\left(\mathrm{E}_{15}\right)$ & 0 & 100 & $\begin{array}{c}\text { Vancomycin } \\
\left(\mathrm{VA}_{10}\right)\end{array}$ & 0 & 100 \\
\hline
\end{tabular}

These results dominstrated that this microbe were sensitive to Imipenem $(27 \mathrm{~mm} /$ disk) forward Ciprofloxacin $(27 \mathrm{~mm} /$ disk) whereas resistant to AM10, E15, CN10, P10 and TMP10 respectively disagreement with result from Khudaier, (2011). The disagreement between present results and Khudaier, (2011) could be due to location where isolates were taken i.e. from Iraq and from India. On the other hand isolates were similar about vancomycin resistance depending on CLSI (2011) which detected the value of this antibiotic was resistance $(\geq 17 \mathrm{~mm})$ and also this study is similar to the study of Albanese and their colleagues (2006).

All of them were sensitive towards imipenem, Bou and their colleagues, (2008) have been demonstrated that out of 42 patients infected with Leuconostoc spp. 9 of the patients died and 3 of the deaths $(7.1 \%)$ were directly related to the Leuconostoc infection and all of them were resistant to vancomycin, Leuconostoc spp. has been considered a high pathogen effected in the immunocompromised host.

\section{Conclusion}

From this article we are advice all clinical diagnostic laboratories to use vancomycin resistance, growth at $10{ }^{\circ} \mathrm{C}$ and glucose fermentation tests to fast detect and separate Leuconostoc spp. from other related genera because these tests are very useful and simply.

\section{REFERENCES}

Albanese, A.; Spanu, T.; Sali, M.; Novezgno, F.; D'Inzeo, T.; Santagelo, R.; Mangiola, A.; Anile, D. and Fadda, G. (2006). Molecular identification of Leuconostoc mesenteroides as a cause of brain abscess in an immunocompromised patient. J. Clin. Microbiol. 44(8):3044-3045.

Alexander, S. K. and Strete, D. (2001). Microbiology: A photographic Atlas for the Laboratory. Benjamin Cummings, An imprint of Addison Wesley Longman, Inc. USA. Pp.35-36.

Atlas, R. (2010). Handbook of Microbiological Media. $4^{\text {th }}$ ed. Talyor and Francis Group, an Information business. USA. P. 463.

Benkerroum, N.; Misbah, M.; Sandine, W. and Elaraki, A. (1993). Development and use of a selective medium for isolation of Leuconostoc spp. from vegetables and dairy product. Appli. and Enviro. Micro. 59(2):607-609. 


\section{Proceeding of $6^{\text {th }}$ nternational Conference of Biotechnology, Environment and Engineering Sciences}

(ICBEI) 28 - 29 December 2019, Alexandria-Egypt

Bou, G.; Saleta, J.L.; Nieto, J.A.; Tomás, M.; Valdezate, S.; Sousa, D.; Lueiro, F.; Villanueva, R.; Pereira, M.J. and Llinares, P. (2008). Nosocomial Outbreaks Caused by Leuconostoc mesenteroides subsp. Mesenteroides. Emerg. Infect. Dis. 14(6):968-971.

Buu-Hoi, A.; Branger, C. and Acar, J. F. (1985). Vancomycin-resistant streptococci or Leuconostoc sp. Antimicrob Agents Chemother. 28(3):458-460.

Cappelli, E. A.; Barros, R. R.; Camello, T. C.; Teixeria, L. M and Merquior, V.C. (1999). Leuconostoc pseudomesenteroides as a Cause of Nosocomial Urinary Tract Infections. J. Clin. Micro. 37(12): 4124-4126.

Clinical and Laboratory Standards Institute CLSI. (2011). Performance Standards for Antimicrobial Susceptibility Testing: TwentyFirst Informational Supplement. 2H-2 31(1):105.

Clinical and laboratory standards institute CLSI. (2018). Performance standards for antimicrobial susceptibility testing: Twenty- eight Informational Supplement. M100. 38(3):23-24.

Elliott, J. A. and Facklam, R. R. (1993). Identification of Leuconostoc spp. by analysis of soluble whole-cell protein patterns. J. Clin. Micro. 31(5): 1030-1033.

Facklam, R. and Elliott, J.A. (1995). Identification, classification, and clinical relevance of catalase-negative, gram-positive cocci, excluding streptococci and enterococci. Clin Microbiol Rev. 8(4): 479-495.

Finegold, S. and Martin, W. (1982). Bailey and Scott's Diagnostic Microbiology. C. V. Mosby Company. Missouri. USA. Pp. 619648.

Helali, A.; McAlear, D. and Osoba, A. (2005). Leuconostoc bacteremia in a child with short-gut syndrome. Saudi Med J. 26(2): 311 313.

Horowitz, H.W.; Handwerger, S.; van Horn, K.G. and Wormser, G.P. (1987). Leuconostoc, an emerging vancomycin-resistant pathogen. Lancet. 2(8571):1329-1330.

Jofré, M.L.; Sakurada, Z.A.; Ulloa, M.T.; Hormázabal, J.C.; Godoy, M.V.; Fernández, O.J.; Gutiérrez, M.M.; Monteverde, M.P.; Castillo, G.M. and Canales, P.A. (2006). Leuconostoc infections in patients with short gut syndrome, parenteral nutrition and continuous enteral feeding. Rev Chilena Infectol. 23(4): 340-345.

Khudaier, B. Y. (2011). Leuconostoc mesenteroides cause Nosocomial UTI At a tertiary care center in North India. J. Thi-Qar Uni. 4(6):23-34.

Kulwichit, W.; Nilgate,S.; Chatsuwan, T.;, Krajiw, S.; Unhasuta, C. and Anan, A. (2007). Accuracies of Leuconostoc phenotypic identification: a comparison of API systems and conventional phenotypic assays. BMC Infect. Dis. 7(69):1-8

Mahon, C. R.; Lehman, D. C. and Manuselis, G. (2011). Textbook of Diagnostic Microbiology. $4^{\text {th }}$ ed. W. B. Saunders Company. CHINA. Pp.: 343-344.

Mahon, C.; Lehman, D. and Manuselis, G. (2015). Textbook of Diagnostic Microbiology. $5^{\text {th }}$ ed. Saunders, an imprint of Elsevier, Inc.

Moschetti, G.; Blaiotta, G.; Villani, F. and Coppola, S. (2000). Specific Detection of Leuconostoc mesenteroides subsp. mesenteroides with DNA Primers Identified by Randomly Amplified Polymorphic DNA Analysis. APPL. ENV. MICRO. 66(1): 422424.

Procop, G.; Church, D.; Hall, G.; Janda, W.; Koneman, E.; Schreckenberger, P. and Woods, G. (2017). Color Atlas and Textbook of Diagnostic Microbiology. $7^{\text {th }}$ ed. Wolters Kluwer. CHINA.

Vandepitte, J.; Verhaegen, J.; Engbaek, K.; Rohner, P.; Piot, P. and Heuck C. (2003). Basic laboratory procedures in clinical bacteriology $2^{\text {ed. }}$. World Health Organization. Geneva. 